Teti Rahmawati \& Yana Handriyana

Corporate Governance to Prevent Financial Distress: Evidence from Corporate Governance Perceptions Index of Indonesian Companies

\title{
Corporate Governance to Prevent Financial Distress Evidence from Corporate Governance Perceptions Index of Indonesian Companies
}

\author{
Teti Rahmawati \\ Economics Faculty, Kuningan University \\ teti.rahmawati@uniku.ac.id \\ Yana Handriyana \\ Economics Faculty, Kuningan University \\ yanadede898@gmail.com
}

\begin{abstract}
This study aims to determine the influence of Good Corporate Governance (GCG), Company Size, Liquidity, and Rentability on Financial Distress of companies listed on Corporate Governance Perception Index (CGPI) partially and simultaneously. The population of this research is companies listed on the Indonesian Stock Exchange (BEI) and Corporate Governance Perception ranks starting from 2013 to 2016. Based on the criteria above, 59 companies are selected. The sampling of this research is taken by using purposive sampling method from the population with a target of several considerations. The result shows that Good Corporate Governance does not significantly influence Financial Distress, Company Size negatively affects Financial Distress, Liquidity positively affects Financial Distress, and Rentability positively affects Financial Distress. Good Corporate Governance, Company Size, Liquidity, and Rentability partially influence Financial Distress with coefficient determination is $92,25 \%$ while $2,75 \%$ is explained by other unobserved variables in outside the model.
\end{abstract}

Keywords: Good Corporate Governance (GCG), Company Size, Liquidity, Rentability, Financial Distress

JEL Classification: G33, G34, M41

\section{INTRODUCTION}

Global Financial Crisis is a situation when all of the economic sectors in the global market have a great deal crisis that affects many sectors of the world. It has serious effects on the economic condition all over the world including Indonesia. In the past 20 years, Indonesia has experienced the economic crisis in 1997 to 1998 as the effect of Global Financial Crisis. In 2008 to 2013 Indonesia faced global financial crisis that seriously affected business in general. The financial crisis caused the bankruptcy of several companies in USA, Europe, and Asia. However, in Indonesia, the 
financial crisis had caused de-listing to several companies. The delisting occurs when its stock listed in stock exchange decreases and is no longer qualified to be included on the list.

During 2013 to 2016 several companies were delisted from the stock exchange. There were 7 companies delisted by BEI in 2013 and it was indicated as the highest number of companies being delisted. One of the reasons the companies were delisted from the stock exchange was because the companies were under financial distress (Pranowo, 2010). Financial distress defined as decreasing financial condition happens before the bankruptcy or liquidity (Platt and Platt 2002). The company tends to face liquidity issues recognized as the inability in making payments to creditors (Hanifah, 2013). The company suffered financial distortions and continued to get financial pressure which gradually further leads to bankruptcy (Platt and Platt 2006). One of the main causes of the crisis in Asia is the weakness in the implementation of Corporate Governance (Husnan 2001, Baird 2000). Poor corporate governance is one of the causes of the economic crisis that occurred in East Asia in 1997-1998, including in Indonesia (Wolfhenson, 1999).

The proper implementation of good corporate governance will improve company's performance and avoid the occurrence of financial distress. The implementation of good corporate governance leads to a decrease in cost of capital and improves the performance of firms (Leal and Carvalhal 2005), reduces agency costs more efficiently and improves company's performance (Fauver and Fuerst, 2004), and reduces corporate profit management (Bowen, Rajgopal, Venkatchalam, 2007). The implication of Good Corporate Governance is enhancing the investors' trust towards company because the risk to manipulate cash flow by the manager is pretty low. Moreover, many investors are interested to invest the financial capital in the company (Garay and Gonzales, 2008). The company's stock price has increased in the market due to the implementation of good corporate governance (Cheung et al, 2005). Beside enhancing a company's performance, Good Corporate Governance is also able to protect the investors in investing the capital (La Porta, Lopez-de-Silanes, Shleifer and Vishy, 2000). A company that publishes Good Corporate Governance gives higher return on investment more than what they expect (Dewi, 2009).

Financial distress can be prevented when the company management runs well even when global crisis occurs. However, in line with the well-management of the company, Good Corporate Governance (GCG) is a system that manages and supervises the company to create the value added to all stakeholders. GCG is a system in managing company both by 
Teti Rahmawati \& Yana Handriyana

Corporate Governance to Prevent Financial Distress: Evidence from Corporate Governance Perceptions Index of

Indonesian Companies

enhancing company's point of view and protecting the whole stakeholders. One of the indicators from the implementation of GCG is by using the CGPI (Corporate Governance Perception Index). Corporate Governance Perception Index (CGPI) is a research and ranking program in terms of GCG implementation for companies in Indonesia. Some companies in Indonesia such as public company, state-owned enterprises, and another private banks and companies join the
CGPI program. CGPI has been consistently held since 2001. CGPI was established by IICG as an independent Non-Governance corporate with SWA Magazine as its media partner. The SWA Magazine will publish the companies ranked on the Corporate Governance Perception Index (CGPI) that are nominated as Most Trusted Company, Trusted Company, and Fair Trusted Company. The table below is the list of the company in CGPI in 2013-2016:

Table 1. Companies listed in CGPI

\begin{tabular}{ccccc}
\hline Year & $\begin{array}{c}\text { Total } \\
\text { Participants }\end{array}$ & $\begin{array}{c}\text { Most Trusted } \\
\text { Company }\end{array}$ & $\begin{array}{c}\text { Trusted } \\
\text { Company }\end{array}$ & $\begin{array}{c}\text { Fair Trusted } \\
\text { Company }\end{array}$ \\
\hline 2013 & 42 & 12 & 26 & 4 \\
2014 & 31 & 11 & 19 & 1 \\
2015 & 23 & 11 & 11 & 1 \\
2016 & 30 & 12 & 18 & -
\end{tabular}

Data was taken from SWA Magazine and analyzed by the researcher

A company is said capable to prevent the financial distress when it pays attention to the company's management. When the company's management runs well, therefore, company size and the financial ratio of the company will enhance. The company's value is not only affected by on how a company is managed, but there are also several ways that possibly involved in measuring whether the company is large or small, such as company size. Size is measured by total assets of the company. Higher total assets owned by a company shows that the company is successfully achieved positive cash flow, therefore the company is able to prevent financial distress. However, it cannot guarantee that a good company size will reflect a good financial ratio, especially liquidity ratio and solvability of the company. A good financial ratio will protect the company from financial distress. Hanifah (2013) stated that financial distress is a company that has liquidity issues that is an inability to make the obligation payments to the creditors, whether it is the long or short term such as liquidity and solvability. 
Liquidity Ratio is a ratio that indicates a company's ability to meet its obligations or pay its short-term debt that is, how capable the company to pay its obligations or debts that have matured. If the company is able to meet its obligations, then the company is said to be liquid. Conversely, if the company cannot fulfill its obligations, then the company is considered as illiquid. At maturity, the company must pay obligations to outside parties (liquidity of business entities), or within the company (corporate liquidity). The company must have the amount of cash or investment or other current assets that can be immediately converted into cash to meet its obligations. As an addition, to support good liquidity, the company should consider the ratio of profitability of the company.

The profitability ratio is the ratio used to measure a company's ability to earn a profit over a certain period. Profitability is a reflection of the efficiency of an enterprise in using its working capital, using the rate of profitability for the size of an enterprise's efficiency is a good way. Thus, it is clear that profitability is a very important thing for the company as an efficiency effort where every company in its operation always try to increase its profit so that profitability asset in accordance with standard. This is closely related to the company's liquidity, if the company has assets of profitability in accordance with the standard, then the company is able to pay shortterm debt so as to create a good corporate liquidity.

Research conducted by Hidayat (2014) related to the prediction of financial distress in manufacturing companies in Indonesia shows that the ratio of leverage (total debt to assets ratio), current ratio and total assets turnover ratio are the financial ratios that are the most significant in predicting the occurrence of financial distress in a company, while the ratio of profitability (return on assets) is the only financial ratio that is not significant in affecting the financial distress of a company. While based on research conducted by Rusaly (2016) known that the ratio of liquidity (current ratio) and the ratio of profitability (return on asset) have negative effect on the company's financial distress and profitability (return on asset) is the most dominant variable affecting financial distress.

The purpose of this study is to understand and find empirical evidence as well as to further analyze how big the influence of Good Corporate Governance, Corporate Size, Liquidity and Rentability to Financial Distress in companies that are ranked in Corporate Governance Perception Index (CGPI) in 20132016.

\section{LITERATURE REVIEW}

Agency Theory

The agency theory is the foundation that companies use to 
Teti Rahmawati \& Yana Handriyana

Corporate Governance to Prevent Financial Distress: Evidence from Corporate Governance Perceptions Index of Indonesian Companies

understand good corporate governance. Company management should be monitored and controlled to minimize asymmetric information and to ensure that management is carried out in full compliance with various rules and regulations. These efforts incur agency costs that are costs that include expenditures for supervision by shareholders and costs incurred by management to produce transparent reports, including independent audit fees and internal controls and costs caused by impairment of shareholder value as a form of bond issuance provided to management in the form of options and benefits for the purpose of aligning management interests with shareholders. One way to reduce the conflict between agents and principals is through disclosure of information by agents in line with the development of good corporate governance issues.

\section{Good Corporate Governance (GCG)} Good Corporate Governance (GCG) is the structure through which shareholders, directors, managers, set the board objectives of the company, the means of attaining those objectives and monitoring performance. Organization for Economic Cooperation and Development (OECD). Corporate Governance Perception Index (CGPI) is a research and ranking program in terms of GCG implementation for companies in Indonesia. Some companies in Indonesia such as public company, state-owned enterprises, and another private banks and companies join the CGPI program. CGPI has been consistently held since 2001. CGPI was established by IICG as an independent Non-Governance corporate with SWA Magazine as its media partner. This program is designed to encourage companies to improve the application of CG concepts through continuous improvement by conducting evaluations and conducting benchmarking. This CGPI program will appreciate those companies that have been implemented CG through CGPI Awards and nominated as The Most Trusted Company. The result of CGPI Awards will be published in SWA Magazine highlights.

\section{Company Size}

Company size is average total net sales during a certain period. In this case the sale is greater than the variable cost and fixed costs, it will result the income before tax. Conversely, if sales are smaller than variable costs and fixed costs then the company will suffer losses (Brigham and Houston 2001). Francis (1986), Grubber and Elton (1995) and Fama and French (1995) in Panjaitan, et al. (2004) argue that firms with small scores tend to be less profitable than large-scale firms. Small companies only have supporting factors to produce goods with limited quantities. Therefore, small-scale companies have a greater risk than large companies. Firms with large risks usually offer substantial returns to attract investors. 
Miswanto and Husnan (1999) in their research regarding the influence of company size on business risks found that company size influenced business risks. According to their empirical data, a small company has higher risk and return compares with a larger company. Mutchler (1985) stated that the auditor was more often highlighted a going concern audit opinion on a small company because the auditor believed that large company can solve the financial crisis than a small company.

\section{Liquidity}

The ratio of liquidity is a ratio that describes a company's ability to pay off all obligations that must be immediately fulfilled (short-term debt). Companies that have enough ability to pay short-term debt are called a liquid company while firms that can not pay short term debt are called illiquid.

\section{Financial Distress}

According to Ross et al. (1986), financial distress is the inability of the company to fulfill its obligations, in other words the company has insolvency. According to Almilia and Herdiningtyas (2005) financial distress is a situation where the company fails or is unable to meet obligations to the debtor because the company is experiencing shortages and insufficient funds in which total liabilities is greater than the total assets, and cannot achieve the company's economic goals.
There are several ways to measure whether or not a company has financial distress. Altman (1968) described financial distress by using numbers in the financial statement and represent them in a number, namely Z-Score which can be a reference to determine whether a company has the potential to go bankrupt or not. Thus, Asquith, Gertner, and Schrtstein (1994) measured financial distress by using interest coverage ratio to defined financial distress. Meanwhile Lou (1987) and Hill et al. (1996) measured by seeing whether there were employees discharge or removal dividend payments. And based on Hofer (1980) and Whitaker (1999), financial distress is the period of the company experiences negative net operating profit.

In 1968, Edwar I. Altman conducted a successful research to create a model known as Altman ZScore, this model is a combination of some financial ratios that can be used in predicting financial distress of a business, as any serious financial distress will direct a company to bankruptcy. The potential of bankruptcy reflected in the Z-score can be useful for both the investor and the company's management. An analysis model called Z-Score has a statistical technique called multiple discriminant analysis (MDA) used to predict a company's bankruptcy.

This scrim analysis is a statistical technique that identifies several types of financial ratios that are deemed to have an important 
Teti Rahmawati \& Yana Handriyana

Corporate Governance to Prevent Financial Distress: Evidence from Corporate Governance Perceptions Index of Indonesian Companies

influence on influencing an event and then develops it in a model with a view to facilitating stakeholders in drawing conclusions from an event. This discriminant analysis then produces an index that allows the classification of an observation of some of the categories that are inherently apriori and fundamental.

This model basically searches for " $Z$ " which is a value indicating the condition of the company, whether it is in healthy condition or not, and shows the performance of the company as well as reflects the prospect of the company in the future. The Altman ZScore model allows to estimate the financial distress up to three years before its arrival.

\section{Theoretical Framework}

The effect of good corporate governance (GCG) on financial distress

The concept of Good Corporate Governance is a well-managedcompany that significantly influence financial distress. Good Corporate Governance negatively influences financial distress. This condition occurs when the company implements well the Good Corporate Governance (GCG). This will reduce the chance of the company experiencing financial distress marked by the increasing value of $Z$ score used as an indicator in this study. According to Komite Nasional Kebijakan Governance (KNKG), Agusti (2013), one of the functions of Good
Corporate Governance (GCG) implementation is to improve the national or international competitiveness of company in order to improve market trust that supports investment and national economic growth continuously. Therefore, it can minimize the chance of a company experiencing financial distress when a global crisis occurs. GCG might be one of the factors to prevent financial distress.

H1 : Good Corporate Governance negatively affects Financial Distress

The effect of company size on financial distress

Company size can be seen from total assets owned by the company. It negatively influences the financial distress. This is because the larger the size of the company, the more robust the company can face any threat of economic crisis. However, it is one of the factors to mitigate the financial distress that recognized by the higher value of ZScore as an indicator used in this study. Wijaya (2015) similarly stated that company size partially and significantly influences financial distress.

H2 : Company size negatively affects financial distress

The effect of liquidity ratio on financial distress

Liquidity shows the ability of the company in making payments to creditors. A company will be said to be close to a financial distress if the 
company has many obligations due. If the company is able to finance and pay off its short-term liabilities well then the company's potential to experience financial distress will be smaller which is marked by a higher Z-Score value. Therefore Liquidity ratio has a positive effect on financial distress. This is because with the higher the value of a company's liquidity, it will increase the prediction value of Z-Score. According to altman $Z$ method if the value of $Z$ is above 2.99 then the company is in the condition of nonfinancial distress, it means that the company is protected from the possibility of bankruptcy. Unlike the Zmijewski X-Score model, the higher the value of $X$, the greater the possibility of companies experiencing financial distress. The ratio of liquidity affects the financial distress.

\section{H3 : Liquidity ratio positively} affects Financial Distress

The effect of rentability (profitability) ratio on financial distress

Rentability ratio or profitability ratio is a ratio used to measure the ability of the company to earn profit. Attention is emphasized on this ratio because it is closely related to the survival of the company. According to Wahyu (in Andre, 2013), rentability or profitability indicates the efficiency and effectiveness of the use of corporate assets because this ratio measures the ability of firms to generate profits based on the use of assets. The effectiveness of the usage of company assets may lead the company to minimize the expenditure. This condition, however, makes the company has a fewer risk of financial distress that recognized by the higher value of $Z$ Score. Thus, rentability ratio positively influences financial distress. The higher value of rentability ratio in the company, the higher value of Z-Score that leads to non-financial distress. As Altman ZScore model explained, when value $Z$ is higher, the higher chance of the company to avoid financial distress. Financial Ratio from ROA significantly influences in predicting financial distress. Therefore this research can be a basis that rentability measured by ROA is able to mitigate financial distress

H4 : Rentability ratio positively affects Financial Distress

\section{METHOD, DATA AND ANALYSIS}

\section{Measurement Variable}

1. Good Corporate Governance (GCG)

in this research is measured by the ranking of Corporate Governance Perception Index (CGPI). Corporate Governance Perception Index (CGPI) is a GCG research and ranking program for companies in Indonesia.

2. Company Size

According to Ferry and Jones (Sujianto, 2001), the company size describes a company whether it is small or large 
company based on total assets, total sale, average of total sale, and average of total assets. In this research, the company size is measured by total assets of the company.

3. Liquidity Ratio

The current ratio is one of the liquidity ratios that generally used to measure a company's liquidity. This ratio compares current assets with current liabilities. Current ratio provides information about the ability of current assets to cover current liabilities. Current assets include cash, accounts receivable, securities, inventories, and other assets. While current liabilities include trade payables, notes payable, bank loans, salary payable, and other payables that must be paid immediately (Sutrisno, 2001).
4. Rentability Ratio

Rentability ratio or profitability ratio is a ratio used to measure and evaluate the ability of the company to generate income (profit). Attention is emphasized on this ratio because it is closely related to the survival of the company.

5. Financial Distress $(\mathrm{Y})$

Financial Distress is the liquidity problem or the inability of the company in making payments to creditors. The condition is more likely when a company faces some difficulties; for instance, the amount of debts is higher than assets. In this research, the financial distress is measured by using Altman Z-Score method.

Hanafi (2009) stated that in determining Z-score there are four indicators combined with Zscore equation, as follows :

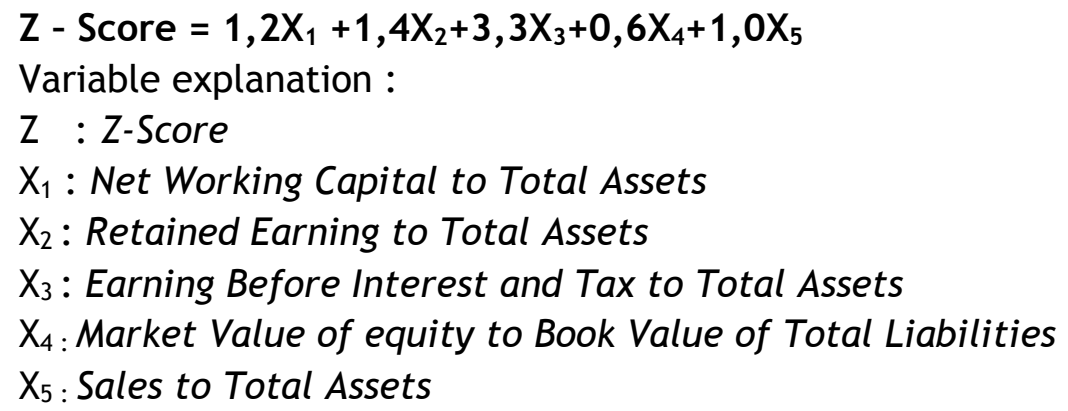

\section{Population and Sample}

The population of this research is companies listed on the Indonesian Stock Exchange (BEl) and Corporate Governance Perception Index ranks starting from 2013 to 2016. Based on the criteria above, 59 companies are selected. The sampling of this research is taken by using purposive sampling method from the population with several considerations. The considerations used in selecting samples are:

1. The companies are listed in BEI

2. The companies are listed on CGPI ranks starting from 2013 to 2016 
3. The companies that constantly sorted on CGPI ranks starting from 2013 to 2016.

\section{Research Model}

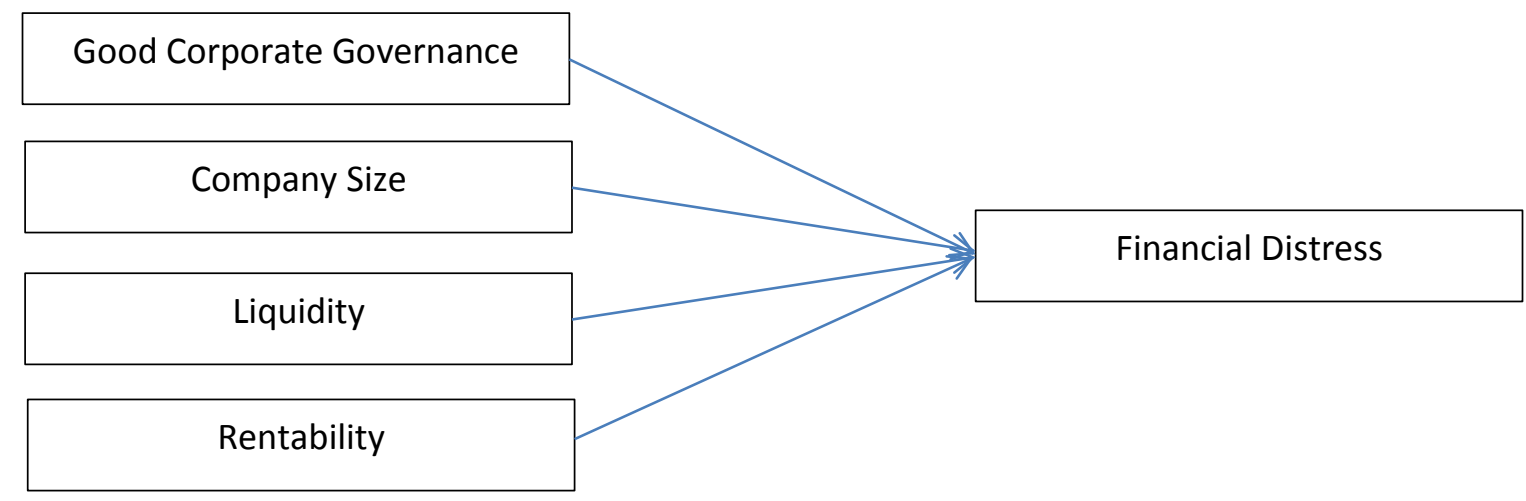

Figure 1. Reserach Model

Multiple linier regression was used for analysis this study.

Regression models that can be

$F D_{i t}=\alpha+$ gcg $_{i t}+\operatorname{Size}_{i t}+$ Liquid $_{i t}+\operatorname{Renta}_{i t}+e$

$\mathrm{FD} \quad=$ Financial Distress,

GCG = Good corporate governance,

Size = Company size,

Liquid = liquidity,

Renta $=$ Rentabilit

\section{RESULT AND DISCUSSION}

This research used classical assumption test in order to determine the proper regression model such as;

normality distribution data, the multicollinearity, autocorrelations, and heteroscedasticity.

Table 2. Deskriptif Analysys

\begin{tabular}{lcccrc}
\hline & GCG & Company Size & Liquidity & Rentability & $\begin{array}{c}\text { Financial } \\
\text { Distress }\end{array}$ \\
\hline Mean & 87.61643 & 5778.212 & 102.4371 & 2.303571 & 3.198571 \\
Median & 87.05500 & 598.7023 & 86.37000 & 2.860000 & 3.200000 \\
Maximum & 93.30000 & 53500.32 & 259.3200 & 4.750000 & 5.540000 \\
Minimum & 84.53000 & 21.86512 & 48.10000 & -5.500000 & 0.690000 \\
Std. Dev. & 2.384949 & 13725.95 & 49.63653 & 2.166575 & 1.484507 \\
Skewness & 1.172520 & 2.384949 & 2.203124 & -2.324043 & -0.002349 \\
Kurtosis & 3.432781 & 7.393020 & 6.841609 & 8.472107 & 1.932853 \\
& & & & & \\
\hline
\end{tabular}


Teti Rahmawati \& Yana Handriyana

Corporate Governance to Prevent Financial Distress: Evidence from Corporate Governance Perceptions Index of Indonesian Companies

\begin{tabular}{lccccc}
\hline Jarque-Bera & 6.634267 & 49.05899 & 39.86847 & 60.14010 & 1.328629 \\
Probability & 0.036257 & 0.000000 & 0.000000 & 0.000000 & 0.514626 \\
& & & & & \\
Sum & 2453.260 & 161789.9 & 2868.240 & 64.50000 & 89.56000 \\
Sum Sq. Dev. & 153.5754 & $5.09 \mathrm{E}+09$ & 66522.20 & 126.7392 & 59.50154 \\
& & & & & 28 \\
Observations & 28 & 28 & 28 & 28 & 28 \\
\hline
\end{tabular}

The result of the test which used chow and Hausman test shows that multiple linear regression models in the research are fixed effect model. Therefore the result of the model as follows:

$$
\begin{aligned}
\mathrm{FD} & =5,225913-2,235709_{\mathrm{ANTAM}}+0,027466_{\text {MANDIRI }}-0,558292_{\mathrm{BRI}}-0,926488_{\text {JMRG }} \\
& +0,024032_{\mathrm{BCA}}+1,665110_{\mathrm{BNI}}+2,003882_{\mathrm{OCBC}}-0,032485 \mathrm{GCG}-2,8705 \text { Size } \\
& +0,006371 \text { Liquid }+0,144225 \text { Renta }
\end{aligned}
$$

Based on the equation of multiple linear regression above, each independent variable that can be interpreted as the influence towards financial distress are:

1. Constant which is 5,225913 implies that if the value of other coefficient variables is 0 then the value of the coefficient of financial distress is 5,225913 .

2. Coefficient of variable $X_{1}$ is 0,032485 that indicates negative influence of GCG to financial distress. if GCG increases by 1 point, then financial distress decreases by 0,032485 point.

3. Coefficient of variable $X_{2}$ is 2,87 that indicates negative relationship between company size and the financial distress. It means if the company size increases by 1 point, the financial distress will decrease by 2,87 points.

4. Coefficient of variable $X_{3}$ is 0,006371 that indicates positive relationship between liquidity and financial distress. It means if liquidity increases by 1 point, the financial distress increases by 0,006371 point.

5. Coefficient of variable $X_{4}$ is 0,144225 that indicates positive relationship between rentability and financial distress. if rentability increases by 1 point, then the financial distress increases by 0,144225 point.

The coefficient determination is interpreted to measure how much a model explains dependent variable. Adjusted Rsquared is 0,972526 means that Good Corporate Governance, Company Size, Liquidity, and Profitability/Rentability reflect 
Financial Distress up to $97,25 \%$. Meanwhile, $2,75 \%$ is explained by other variables that are not included in this research.

\section{Simultaneous Test}

Based on the analysis, $F_{\text {statistic }}$ is 96,57633 with a significance level is
0,00000 . Value of $F_{\text {statistic }}>F_{\text {table }}$ is $96,57633>2,80$ with a significance value is $0,0000<0,05$, therefore, Ho rejected and $\mathrm{Ha}$ reflects Good Corporate Governance, Size of Company, Liquidity, and Probability significantly affect the financial distress.

Table 3. Simultaneous Test

\begin{tabular}{llll}
\hline \hline R-squared & 0.982702 & Mean dependent var & 3.198571 \\
Adjusted R-squared & 0.972526 & S.D. dependent var & 1.484507 \\
S.E. of regression & 0.246059 & Akaike info criterion & 0.320234 \\
Sum squared resid & 1.029267 & Schwarz criterion & 0.843600 \\
Log likelihood & 6.516723 & Hannan-Quinn criter. & 0.480232 \\
F-statistic & 96.57633 & Durbin-Watson stat & 3.221313 \\
Prob(F-statistic) & 0.000000 & & \\
\hline \hline
\end{tabular}

\section{Partial Test}

Therefore, it can be inferred from the model of this research, as follows:

Table 4 shows that Variable $X_{1}$ has $t_{\text {statistic }}-0,367520$ with significance level of 0,7178 . The value of $-t_{\text {statistic }}>$ - $t_{\text {table }}$ is $-0,367520>-1,71088$ with significance level of $0,7178>0,05$ indicates that Ho is approved. While, $\mathrm{Ha}$ that indicates good corporate governance significantly affects financial distress is rejected. On the other hand, Good Corporate Governance does not significantly affect financial distress.

Variable $X_{2}$ has value of $t_{\text {statistic }}$ 2,149436 and significance level of 0,0463 . The value of $-t_{\text {statistic }}<-t_{\text {table }}$ is $-2,14936<-1,71088$ with significance level of $0,0463<0,05$, therefore, Ho is rejected. While $\mathrm{Ha}$ which reflects company size significantly affects the financial distress is approved. It can be inferred that company size has significant and negative effect on financial distress.

Variable $X_{3}$ has value of 2,199532 with significance level of 0,0420 . The value of $t_{\text {statistic }}>t_{\text {table }}$ is $2,199532>1,71088$ with significance level of $0,0420<0,05$, therefore, Ho is rejected. While $\mathrm{Ha}$ which indicates liquidity significantly affects financial distress is approved. The result shows that $t_{\text {statistic }}$ is higher than $t_{\text {table }}$ which means liquidity has significant and positive effect on financial distress.

Variable $X_{4}$ value is 3,441003 with significance level of 0,0031 . The value of $t_{\text {statistic }}>t_{\text {table }}$ is $3,441003>$ 1,71088 with significance level of $0,0031<0,05$, thefore, Ho is rejected. While $\mathrm{Ha}$ that indicates rentability has significant effect on financial distress is approved. The result shows that $t_{\text {statistic }}$ is higher than $t_{\text {table }}$ which means rentability have significant and positive effect on financial distress. 
Table 4. Partial Test Result

\begin{tabular}{llllll}
\hline \hline Variable & \multicolumn{2}{c}{ Coefficient Std. Error } & t-Statistic & Prob. & Result \\
\hline \hline C & 5.225913 & 7.720191 & 0.676915 & 0.5076 & \\
CGPI & -0.032485 & 0.088389 & -0.367520 & 0.7178 & HO accepted No significant \\
TA & $-2.87 E-05$ & $1.34 \mathrm{E}-05$ & -2.149436 & 0.0463 & HO Rejected Significant \\
CR & 0.006371 & 0.002897 & 2.199532 & 0.0420 & HO Rejected Significant \\
ROA & 0.144225 & 0.041914 & 3.441003 & 0.0031 & HO Rejected Significant \\
\hline
\end{tabular}

The effect of good corporate governance on financial distress

Statistics test proved that Good Corporate Governance does not significantly influence financial distress on $5 \%$ significance level. Therefore, the hypothesis proposed in this research has been rejected. The insignificancy shows that the result of this research is not general. Only a few number of companies that have been observed. The coefficient regression is $-0,032485$ represents an increase of $1 \%$ will predictably decrease the value financial distress by $0,032485 \%$.

Good Corporate Governance does not significantly influence financial distress. It is because good corporate governance measured by corporate governance perception index does not guarantee whether or not a company has financial distress. It can be explained that corporate governance perception index only influences the company image or market value in order to gain the social trust to the company.

The effect of company size on financial distress

Statistics test shows that company size has negative and significant influence on financial distress at $5 \%$ significance level. The hypothesis proposed in this research has been accepted. The coefficient regression is $-2,87$ shows an increase of $1 \%$ will predictably decrease the financial distress by $2,87 \%$.

The size of a company describes how much of an asset the company has. It can be seen from total assets of the company. This can be seen from the total assets of the company. The larger the size of the company, the more the number of assets owned by the company. Companies will be more stable and more resilient to the threat of financial distress if the company has a large amount of assets. Wijaya (2015) stated "Company size significantly impacts financial distress".

\section{The effect of liquidity on financial distress}

According to the test, liquidity has positive and significant impact on financial distress at $5 \%$ significance level. The hypothesis proposed in this research has been accepted. Significance means the result of this research is general. It does not only apply to the companies observed. The coefficient regression is 0,006371 
indicates that if liquidity increase by $1 \%$, predictably financial distress will increase by $0,006371 \%$.

It is supported by previous research conducted by Hidayat (2013), he stated "Liquidity can arise as a result of past decisions of the company regarding funding from third parties, both in the form of assets and cash. From the decision, it will result in payment obligations in the future. Liquidity is related to how much the company's ability to pay off its financial obligations that have matured."

\section{The effect of rentability on financial distress}

Based on the statistics test, rentability has positive and significant effect on financial distress at $5 \%$ significance level. Therefore, the hypothesis proposed in this research has been accepted. Significance shows the result of this research is general, it also applies to the unobserved companies. The coefficient regression is 0,144255 means that if liquidity increases by $1 \%$ then predictably the financial distress will increase by $0,144155 \%$.

Financial ratio from ROA (liquidity) has significant effect in predicting financial distress. Profitability or rentability can arise on the success of the company in marketing the product / service, the success of marketing is the company's success in selling its products. On the sale, then the profit will be obtained by the company. Profit obtained can be used for the purpose of business expansion or payment of obligations of the company both short and long term, so this will create the stability of the company and avoid the condition of financial distress.

The effect of Good Corporate Governance, Company Size, Liquidity, And Rentability on Financial Distress

Based on the statistics test, Good Corporate Governance, Company Size, Liquidity, and Rentability have significant effect on financial distress at $5 \%$ significance level. Significance means the result of this research is general. It applies to unobserved companies. The analysis of coefficient determination indicates that Good Corporate Governance, Company Size, Liquidity, and Rentability are representing the effect of Financial Distress up to $97,25 \%$. Meanwhile, $2,75 \%$ is explained by other variables outside the model.

\section{CONCLUSION}

Based on the data analysis elaborated in the previous chapters, provided by several ground theories and previous studies, we can conclude that:

1. The result of statistics test shows that good corporate governance does not significantly affect financial distress.

2. Company size has significant and negative effect on financial distress.

3. Liquidity has significant and positive effect on financial distress. 
4. Rentability has significant and positive effect on financial distress.

5. Good corporate governance, company size, liquidity, and rentability simultaneously effect financial distress.

6. The analysis of coefficient determination indicates that Good Corporate Governance, Company Size, Liquidity, and Rentability explain the impact of Financial Distress up to $97,25 \%$. Meanwhile, $2,25 \%$ is explained by other variables outside the model.

\section{SUGGESTIONS}

Based on the conclusions, there are several suggestions need to be considered for the further research specifically on financial distress, as follows:

1. The result shows Good Corporate Governance does not have impact on financial distress. It means that the ranking of corporate governance perception index has effect only on the company's image and value. Therefore, it does not affect the company's potential of financial distress. Therefore, there is a need for counseling about the implementation of Good Corporate Governance in the company and awareness raising from the company management on the importance of Good Corporate Governance, since the implementation of
Good Corporate Governance is still very low in Indonesia.

2. The result shows company size has significant and negative impacts on financial distress. Therefore, the company needs to strengthen the company assets in order to prevent the financial distress and stabilize the current condition of the company.

3. The result shows liquidity and rentability have significant and positive impact on financial distress. Therefore, the company should enhance or maintain stable value of liquidity ratio and rentability ratio. The higher the value of current ratio and ROA, the higher the value of Z-Score or prediction value of a company experiences financial distress. This scenario will potentially minimize the chance of a company experiences financial distress. This is because the profitability can arise because of the success of the company in selling products / services and marketing success, thus creating a relatively stable profit or high profit. Higher profitability will also affect the company's liquidity.

4. Judging from the limitations of variables, samples, number of years and coefficient of determination of $92.25 \%$ then there are $2.75 \%$ other variables that affect financial distress outside the model. To that end, 
the researcher suggests using other financial ratios to get more varied results, such as leverage ratio, activity ratio or adding other variables that affect financial distress.

5. Development of financial distress value calculation technique, which is not only limited to using Z-Score method but can be replaced, for example, the X-Score.

6. It needs to be reviewed again in the future, because the CGPI rating and the number of company assets will change every year, so the ratio values will also change. This will affect the results of further research.

7. Development of different data analysis techniques, so that more accurate results are obtained.

\section{REFERENCE}

Agusti, Restu \& Pertiwi, N.P. (2013). Pengaruh Kompetensi, Independensi, dan Profesionalisme Auditor terhadap Kualitas Audit. Jurnal Ekonomi, 21(3), 1-13.

Almilia, L. S., \& Herdiningtyas, W. (2005). Analisis Rasio CAMEL Terhadap Prediksi Kondisi Bermasalah Pada Lembaga Perbankan Periode 2000 -2002. Jurnal Akuntansi dan Keuangan, 7(2), 11-147.

Altman, E., \& McGough, T. (1974). Evaluation of A Company as A Going Concern. Journal of Accountancy, 50 -57.
Asquith P., Gertner R., \& Scharfstein, D. (1994). Anatomy of Financial Distress: An Examination of JunkBond Issuers. The Quarterly Journal of Economics, 109(3), 625-658.

Baird, M. 2000. The Proper Governance of Companies Will Become as Crucial to the World Economy as the Proper Governing of Countries. Paper.

Bowen, R. M, Rajgopal. S, \& Venkatachalam. M. (2007). Acstatisticing Discretion, Corporate Governance and Firm Performance (Unpublished Thesis, School of Business, University of Washington. Seattle).

Brigham, E., F. \& Houston, J., F. (2014). Essentials of Financial Management ( $3^{\text {rd }}$ ed). Canada: Cengage Learning-Asia.

Cheung, Y., Connelly. J., T., Limpaphayom. P, \& Zhou, L. (2005, Desember 1-38). Do Investors Really Value Corporate Governance? Evidence from the Hong Kong Market. Working Paper of Hong Kong Institute for Monetary Research. Retrieved from

http:/ /www.hkimr.org/uploads/ publication/216/ub_full_0_2_12 2_wp200522_text.pdf.

Dewi, N., H., U. (2009). Corporate Governance in The Effort of Increasing the Company's Value. Journal of Economics, Business, and Accounting.

Fama, E. F., \& French, K. R. (1995). Size and book-to-market factors 
in earnings and returns. The Journal of Finance, 1(1), 131-155.

Elton, E. J., Gruber, M. J., \& Blake, C. R. (1995). Fundamental Economic Variables, Expected Returns, and Bond Fund Performance. The Journal of Finance, 50(4), 1229-1256.

FCGI. 2002, Tata Kelola Perusahaan (CG); The Essence of Good Corporate Governance; Konsep dan Implementasi Perusahaan Publik dan Korporasi Indonesia. Yayasan Pendidikan Pasar Modal Industri \& Sinergy Communication. Jakarta.

Fama E. F., \& French K. R. (1992). The cross-section of expected stock returns. The Journal of Finance, 47(2), 427-465.

Fama E. F., \& French K. R. (1993). Common Risk Factors in the Returns on Stocks and Bonds. Journal of Financial Economics, 33, 3-56.

Fauver, L dan Fuerst, M., E. (2004, 22 April). Does Good Corporate Governance Include Employee Representation? Evidence from German Corporate Boards. Paper presented at EFA 2004 Maastricht Meetings. Retrieved from https://papers.ssrn.com/sol3/p apers.cfm?abstract_id=534422.

Garay, U., \& Gonzales, M. (2008). Corporate Governance and Firm Value: The Case of Venezuela. Corporate Governance International Review, 16(3), 194-209.

Hanifah, O. E., \& Purwanto, A. (2013). Pengaruh

Struktur
Governance dan Financial Indicators Terhadap Kondisi Financial Distress. Diponegoro Journal of Accounting, 2(2), 115.

Hidayat, M. A., \& Meiranto, W. (2014). Prediksi Financial Distress Perusahaan Manufaktur di Indonesia. Diponegoro Journal of Accounting, 3(3), 1-11.

Hill, N. T., Perry, S. E., \& Andes, S. (2011). Evaluating firms in financial distress: an event history analysis. Journal of Applied Business Research, 12(3), $60-71$.

Hofer, C. W. (1980). Turnaround Strategies. Journal of business strategy, 1(1), 19 - 31.

Husnan, S. (2001). Corporate Governance dan Keputusan Pendanaan: Perbandingan Kinerja Perusahaan dengan Pemegang Saham Pengendali Perusahaan Multinasional dan Bukan Multinasional. Jurnal Riset Akuntansi, Manajemen, dan Ekonomi, 1(1), 1-12.

Miswanto \& Husnan, S. (1999). The Effect of Operating Leverage, Cycality, and Firm Size on Business Risk. Gadjah Mada International Journal of Business, $1(1)$.

Mutchler, J. F. (1984). Auditor's Perceptions of the Going Concern Opinion Decision. Auditing: A Journal of Practice \& Theory, 17-30.

La Porta, R., Lopez-de-Silanes, F., Shleifer. A., \& Vishny, R. (2000). Investor Protection and 
Corporate Governance. Journal of Financial Economics, 58(1-2), 3-27.

Lau, A. H. (1987). A Five-State Financial Distress Prediction Model. Journal of Accounting Research, 25(1), 127 - 138.

Leal, R. P. C., \& Carvalhal, A. (2005). Corporate Governance and Value in Brazil (and in Chile). Paper. Retrieved from https: / / ssrn.com/abstract $=7262$ 61.

Platt, H. D., \& Platt, M. B. (2002). Predicting Corporate Financial Distress: Reflecyions on choicebased sample bias. Journal of Economics and Finance, 26(2), 184-199.

Platt, H. D dan Platt. M., B. (2006). Comparing Financial Distress and Bankruptcy. Review of Applied Economics, 2(2), 1-27.

Pranowo, K., Achsani. N. A., Manurung. A. H., \& Nuryartono. N. (2010). Determinant of Corporate Financial Distress in an Emerging Market Economy: Empirical Evidence From Indonesian Stock Exchange 2004-2008. International Research Journal of Finance and Economics, 52, 81-90.

Ross, S. A., Westerfield, Shleifer, A., En Vishny, R. W. (1986). Large Shareholder and Corporate Control. The Journal of Political Economy, 94(3), 461 - 488.

Whitaker, R. B. (1999). The Early Stages of Financial Distress. Journal of Economics and Finance, 23, 123-133.
Wijaya, W. M. (2015). Pengaruh Rasio

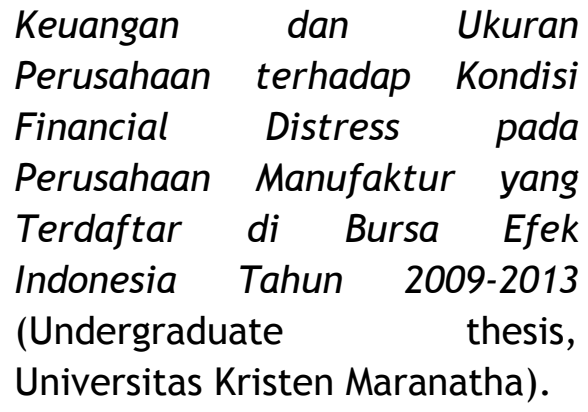

